\title{
Peopling Prehistoric Coastlines: Identifying Mid-Holocene Forager Settlement Strategies in Northern Norway
}

\author{
Charlotte Brysting Damm ${ }^{1}$ (D) Marianne Skandfer ${ }^{2}$ (D) Peter D. Jordan ${ }^{3}$ (D)
}

Accepted: 25 October 2021 / Published online: 8 December 2021

(c) The Author(s) 2021

\begin{abstract}
In circumpolar regions, coastlines offer rich constellations of diverse resources and have long been a focus of human habitation. Despite the rich archaeological records that are located along many northern coastlines, there is a relatively limited understanding of the range of factors that informed local settlement strategies. Northern Norway has one of the world's longest and best-preserved archaeological records of coastal habitation due to post-glacial uplift. Occupation begins in the early Holocene and appears to peak in the mid-Holocene. Our aim in this paper is to investigate the constraints and opportunities that informed the mid-Holocene settlement patterns, between c. 5000 and $0 \mathrm{BC}$. We present new data that were generated by intensive field surveys and undertake a qualitative multiscalar analysis of site-locational choices, evaluating the influences of geography, topography and seasonal resource availability. Having identified stretches of the rugged coast as uninhabitable, we proceeded with analyses of the rest of the coastline. Our results indicate that all major settlements were sited to provide safe boat landing, good vantage points and shelter from storms. From these habitation sites, boat technology would have provided flexible access to diverse resources that were available throughout the year, and within a limited travel radius. We also demonstrate that these settlement strategies contrast with the way that the same coastlines were inhabited by pioneering groups in the early Holocene but appear to have some similarities with mid-Holocene coastal settlement patterns in Newfoundland and the Aleutian Islands. Overall, our results suggest that the multiple resources available along northern coastlines often enabled populations to occupy relatively localized areas for long periods. Longer-range mobility and interaction may instead have been primarily driven by socio-political factors rather than subsistence needs.
\end{abstract}

Keywords Spatial demography $\cdot$ Topography $\cdot$ Location preferences $\cdot$ Forager mobility · Coastal resources

Charlotte Brysting Damm

charlotte.damm@uit.no

1 Department of Archaeology, History, Religious Studies and Theology, UiT-Arctic University of Norway, Troms $\emptyset$, Norway

2 Arctic University Museum, UiT-Arctic University of Norway, Troms $\emptyset$, Norway

3 Department of Archaeology and Ancient History, Lund University, Lund, Sweden 


\section{Introduction}

Northern coastlines can be rugged, but also offer scope for human settlement with ready access to dense constellations of marine, coastal and terrestrial resources, and have attracted increasing human settlement throughout the Holocene (Bjerck 2009; Fitzhugh 2016). Here we aim to reconstruct coastal forager strategies that underpin spatial demographic patterns commonly observed in northern latitudes through a targeted case-study situated in the counties of Troms and Finnmark, which we term northernmost Norway.

Norway has one of the fullest and most complete records of intensive coastal exploitation which extends as far back as the start of the Holocene. Northernmost Norway witnessed an increased density of coastal sites during the mid-Holocene, here defined as $5000-0$ BC. The cool climate and rather exposed coastal location that faces out onto the North Atlantic and Barents Sea result in sparse vegetation cover and slow sedimentary build-up. Much of the region also has limited modern infrastructure. These circumstances have left stretches of ancient raised coastline relatively intact, with imprints of prehistoric dwellings visible as tent rings, cleared floors or house-pits. The archaeological data in this region are therefore particularly well suited to address patterning in mid-Holocene coastal habitation.

While the volume of remains has long been noted for the mid-Holocene and is now found to correspond to a marked population increase (Jørgensen 2020a), there has to date been no systematic attempt to understand what drove the mid-Holocene forager settlement patterns in northernmost Norway, nor to document potentially relevant factors. Site distribution and location factors are crucial elements in site differentiation and in structuring the dynamics between demographic clustering, environment and resources. Both are also both fundamental to analyses of demographic and foraging patterning and strategies.

In existing records, site descriptions are often limited to a short and general presentation of where individual sites are located, and spatial analyses focus on broad categories such as inland and coast. Discussions have centred on whether sites were found deep into fjords or further out, and in particular on the extent of mobility versus semi-sedentary occupation (e.g. E. Helskog 1983; Renouf 1989; Olsen 1994; Schanche 1994), and on the size of residential units (Helskog 1984; Schanche 1994). This debate has, however, not been active since the mid-1990s. Similarly, studies typically focus on direct evidence for resource exploitation, while a comprehensive discussion of the seasonal resource spectrum and how humans positioned themselves to harvest is lacking. To close this gap in knowledge, a targeted analysis, using a qualitative approach, offers one means to reconstruct how choices and strategies were potentially influenced by topography, resource availability and a range of other, more human-scale, factors.

The research project Stone Age Demographics: multi-scale exploration of population variations and dynamics (Damm et al. 2020) designed an approach to investigate regionwide spatial site distribution as well as a range of site location factors. This was tested in surveys for Stone Age sites on the southwestern part of the island of Sørøya in western Finnmark (Fig. 1). By focusing efforts on understanding the dynamics of a geographically compact region, we were able to (a) investigate settlement patterns in relation to a range of geographical and topographical factors and (b) suggest how these were related to the spatial and seasonal availability of marine, coastal and terrestrial resources.

In this case study, we aim to explore coastal forager settlement choices with regard to spatial distribution, site location qualities and local resource availability in a high latitude environment. These are factors pertaining to economic strategies such as choice of 


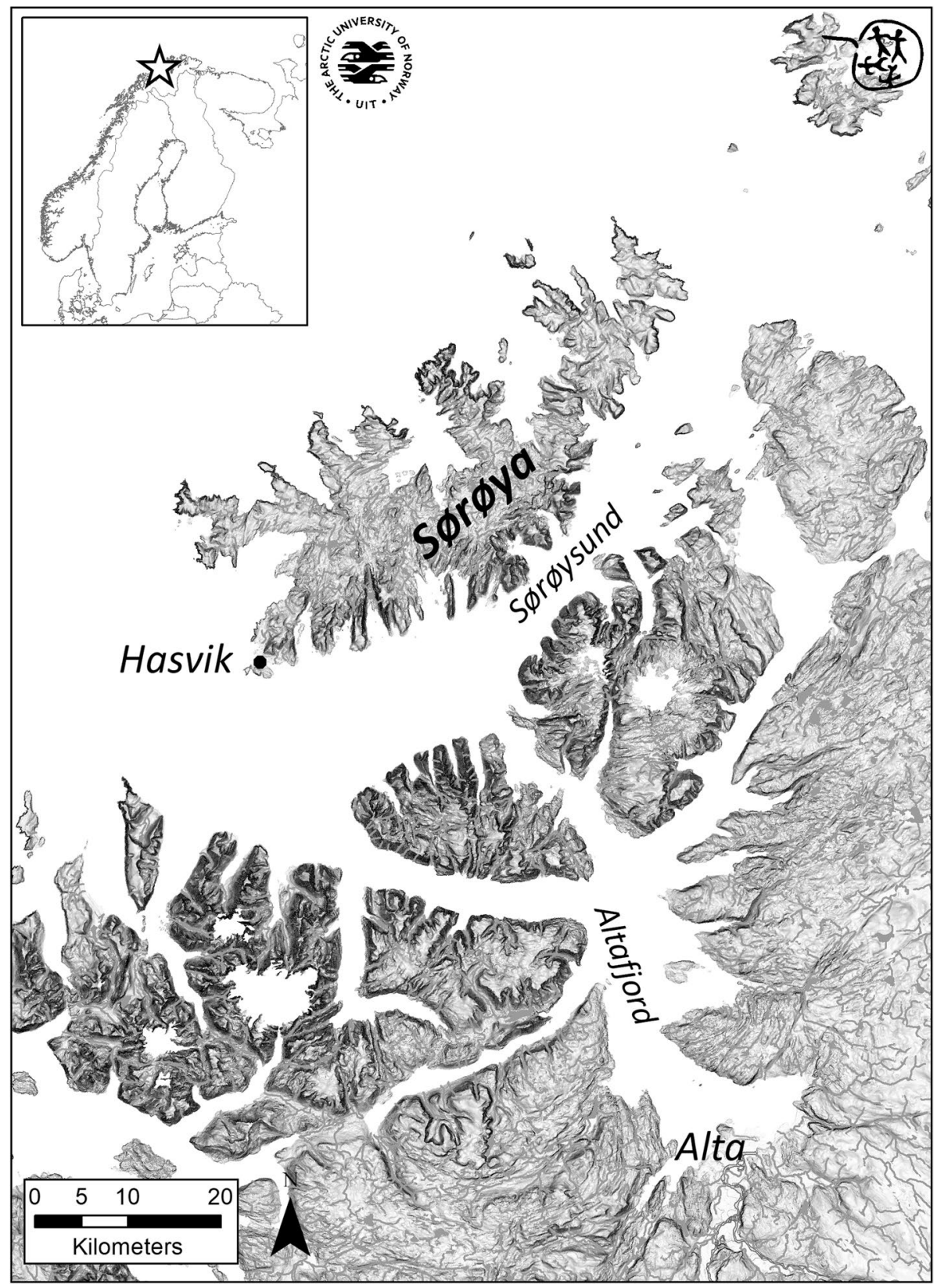

Fig. 1 Western Finnmark in Northern Norway. (Map: G. Skogvold)

resources, the extent of daily and seasonal mobility, as well as to settlement amenities, e.g. valuing fresh water over outlook. We achieve this through extensive surveys and re-documentation of sites resulting in high-resolution data on spatial distribution and site location preferences. Having identified specific settlement patterning in relation to topography 
and available resources, we then compare the mid-Holocene pattern with occupation in the early Holocene of Northern Norway. For this earlier period, there has been focused studies of settlement patterns and site location factors (Bjerck 1989, 1990; Grydeland 2005), and the comparison will show whether other modes of inhabitation are possible in the given local topography. We then expand outwards to a comparative analysis of mid-Holocene occupations in two other circumpolar regions-Newfoundland and the Aleutians-to explore if similarities in patterns and strategies can be inferred.

\section{Study Region: Southwestern Sørøya}

The coastline of northernmost Norway is broken by fjords and bays and has numerous smaller and larger islands, resulting in many sounds. The coast is overall rugged and frequently rocky, often with high cliffs, but has some strandflats and beaches (Fig. 2). While there are many smaller rivers and brooks, the major rivers are generally found at the head of deeper mainland fjords.

Our study region is the southwestern part of the island Sørøya in western Finnmark, northernmost Norway (Figs. 1 and 3). The area was selected due to its varied topography and variability in known site sizes and locations, which made it suitable for a detailed study of a limited geographical region. Furthermore, southwestern Sørøya had seen little research compared to many other parts of northernmost Norway and none since the early 1970s, so an update of the existing records was necessary for the purpose of understanding the Stone Age demography in the wider geographical region. In other parts of the Sørøysund region, there has been numerous research excavations in the 1960s and 1970s, unfortunately mainly unpublished, and two more recent extensive development led campaigns (Hesjedal et al. 1996, 2009; Henriksen \& Valen 2013). This material has only to a very limited degree been activated in discussions of settlement patterns.

Sørøya is at $812 \mathrm{~km}^{2}$ the fourth largest island in Norway, situated at $70^{\circ} \mathrm{N} 22^{\circ} \mathrm{E}$. It is orientated roughly NE-SW and is approximately $64 \mathrm{~km}$ long. As the rest of the coast, it

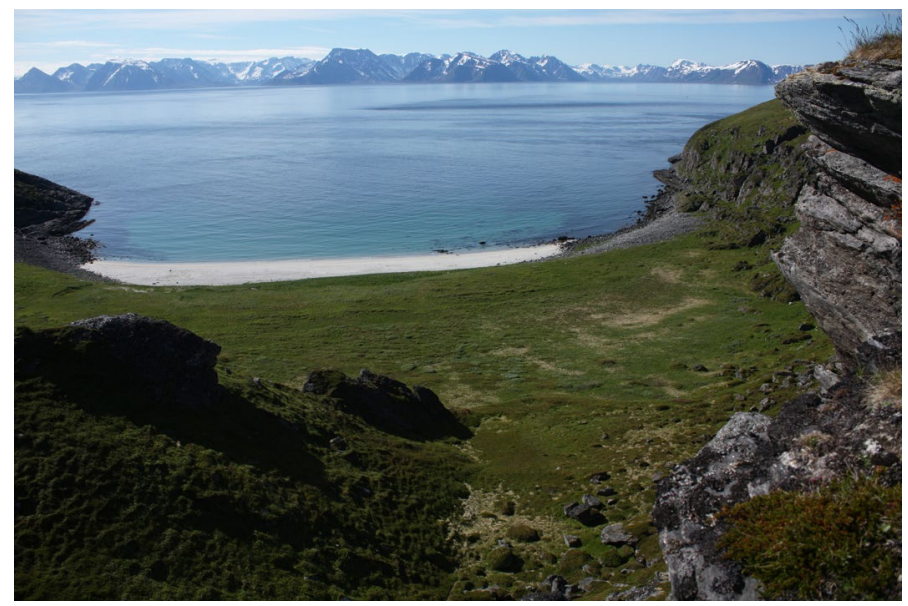

Fig. 2 The coast is rugged and rocky and characterized by many steep cliffs, but also some strandflats and beaches. Here Store Sandvik (site 18 in the Hasvik sub-area). The dwellings are located on the edge of a steep $6 \mathrm{~m}$ high incline not visible here. (Photo: E.K. Jørgensen) 


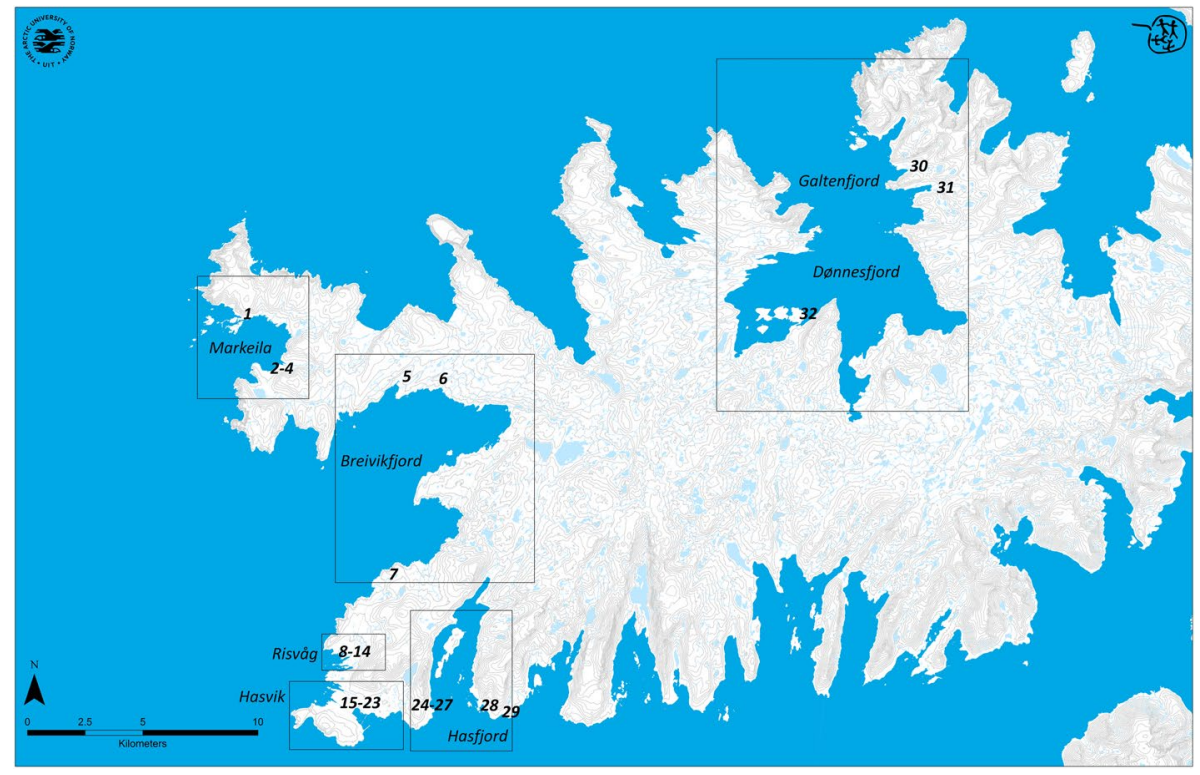

Fig. 3 Southwestern Sørøya with sites and sub-areas according to Table 1. (Illustration: G. Skogvold)

has many fjords and bays, which are widest and longest on the outer northwestern part of the island. This outer part is exposed to open sea and harsh weather from the west and northwest and challenging to navigate in small boats. Southeast of the island is a wide sound, Sørøysund, which although sheltered by low mountains on both sides is known as a rough stretch of water. The wind in the area comes almost exclusively from two directions: W-NW and SE, and storms are frequent in the autumn and winter (Den Norske Los 2018:195). While northwesterlies are generally associated with cold and wet weather, during southeasterly winds, Sørøysund becomes divided into a windy southern part and a calmer northern part. The common strong fallwinds below steeper cliffsides are known to be a risk for smaller boats. The island interior is low (the highest point is 659 masl) with a good deal of bog and small freshwater lakes, but easily traversed once one accesses the plateau.

The climate in the region is warmer than other circumpolar areas at the same latitude, due to the warm North Atlantic Current. The mean temperatures on Sørøya for January and July is $-2^{\circ} \mathrm{c}$. and $11^{\circ} \mathrm{c}$, respectively (1960-1991). Despite the high latitude, the sea around Sørøya never freezes, apart from the shallow, innermost parts of some of the fjords. The dark season, when the sun does not rise above the horizon, lasts two months from late November to late January. Due to the exposed location, mountainous landscape and sparse strand flats, the vegetation on Sørøya was dominated by heath and grassland throughout the Holocene, although birch forest and birch woodland were found in favourable areas, particularly during the Holocene maximum c. 6000-4000 BC (Sjögren \& Damm 2019).

The deglaciation of the coast took place approximately 11,500 BC (Hughes et al. 2016) and was followed by a marked isostatic uplift. As a result, the shoreline in our study region fell, but this was followed by a transgression flooding old beaches and depositing sediments composed of gravel and stones culminating c.5000 BC. In many places, this resulted in marked beach ridges, the top of which today lie between 12 and 15 masl. In other places, 
old beach terraces were eroded. From c.5000 BC onwards, there has been a slow isostatic uplift (Møller 1987; Romundset et al. 2011). The shoreline displacement varies significantly along the coast, but for our study region the sealevel during the mid-Holocene was roughly 8-10 $\mathrm{m}$ above the present (for details see supplementary information, Fig. 1).

\section{Material and Methods}

The study is based on visible dwelling remains, which provide firm evidence for residential occupation. Hardly any surface lithic scatters were identified during our fieldwork. Within the time frame for the current project, it was not possible to include systematic testpitting for the entire area, hence lithic scatters are not included. Consequently, we are investigating settlement patterns for habitation presumably of some duration. Locations for shorter stays and sites where no substantial dwellings were constructed are not included.

Although a few sites and individual structures in the study region pre-date the MidHolocene, by far the majority of the sites and dwellings are located on beach ridges and terraces created during and after the maximum of the marine transgression culminating c. 5000 BC. The use of the house-pit dwellings we focus on were in general discontinued towards the end of the first millennium BC, chronologically delimiting our study period to c. 5000-0 BC.

Only a small number of dwellings from the region have been excavated and there are radiocarbon dates from even fewer. Nevertheless, we know from other excavations that many sites were inhabited repeatedly across several millennia and represent palimpsests of re-occupation. This is evident at larger sites through the number of dwellings on beach terraces at different levels, but new analyses also reveal extensive re-use of the house-pits (Vollan in press). Since many sites were re-occupied repeatedly, and the key characteristics of the sites in most cases did not alter significantly, we do not divide our data into smaller chronozones.

For the purpose of investigating settlement strategies, we needed to generate a comprehensive high-resolution dataset of mid-Holocene habitation sites in a compact yet diverse study region. We designed a field survey approach that build on four parameters: 1) mapping sites and ascertaining the absence of sites; 2) systematically recording topographical features at each site; 3) georeferencing individual archaeological structures; and 4) obtaining local information on resources, climate and landscape qualities. To this field-based approach was added archival information on archaeological sites, weather conditions and resources.

We conducted extensive summer field surveys over several years which involved meticulous documentation to record new insights into site distribution and density (Jørgensen et al. 2019; Skandfer \& Damm 2019; Damm \& Skandfer 2020; Skandfer et al. 2020). The coastal topography of Southwestern Sørøya is rugged, with long stretches of steep cliffs that cannot be settled. Interspaced with these are more sheltered fjords, bays and coves, some with beach ridges and terraces with well-drained sediments. We surveyed all areas that would potentially allow prehistoric settlement, focussing on both presence and absence of evidence for prehistoric habitation. Some known sites and individual structures were destroyed over the last few decades and details could not be recorded anew. Such sites are included here if there is reliable previous information.

It is long recognized that in northernmost Norway sites with house-pits are typically found on old beach ridges, and therefore on well-drained gravel and beach stone 
sediments. Other factors influencing the choice of site location have not been investigated. To remedy this knowledge gap, qualitative information on the topography for each site was systematically documented in our study. This included description of the terrain and surrounding environment, landing conditions, exposure, outlook to other sites or landscapes, access to fresh water and access to other resource areas.

The surveys generated abundant new data and augmented the records by checking the veracity of earlier work in the region. A significant part of the fieldwork was direct observation and recording of the landscape and continuous on-site discussion about the choices behind site locations, placement of individual structures, access to and availability of resources.

Each visible structure (mainly dwelling remains) at the sites was georeferenced. At some sites, the individual structures were documented in detail with georeferenced plan, textual description and photos. At others, only a central point in each dwelling was georeferenced due to either dense vegetation or lack of time. In a few cases, individual dwellings could no longer be identified and hence could not be georeferenced.

Important information on regional and local topographical conditions and local resources such as fishing and hunting grounds, bird colonies, weather conditions and treacherous coastal waters were obtained from local informants. Information was also retrieved from reports on historical land use (Henriksen 2021; Myrvoll et al. 2011), archaeological databases (Askeladden and Musit) and online records of ecology and habitats produced by national archives and research institutions (Institute of Marine Research, Norwegian Biodiversity Centre, Norwegian Polar Institute).

\section{Mapping Site Distributions}

As a result of the new surveys, 32 sites are now identified (Fig. 3), nine of which were previously undiscovered. 115 new dwelling structures were recorded, partly at previously known sites (Table 1). As part of a rigorous approach, we applied a cautious estimate of structures at sites where modern disturbance hindered re-documentation by reducing the number of dwellings at such sites with up to $50 \%$ from past records, leaving us with a total of 310 individual dwellings for the current study.

The spatial distribution of the 32 sites demonstrates that they are linked to natural geographical landscapes or sub-areas. Three such delimited sub-areas are immediately identifiable (Figs. 3 and 4). Markeila bay, Breivikfjord and Galtenfjord/Dønnesfjord on the outer northern side of Sørøya are each a distinct seascape with similar numbers of sites and dwellings. The total of 108 dwellings in this northern part of the study region make up $34.8 \%$ of all dwellings. (Table 2).

The remaining 22 sites with 202 dwellings (65.2\%) are found on the southern edge of the island in an area with more strandflats. At first sight, the large number of sites and dwellings here appear to be relatively evenly spread out. However, the regression of the shoreline has made more significant changes to the landscape in this part of the study region than in the first three sub-areas. By reconstructing the prehistoric coastline with a $10 \mathrm{~m}$ higher coastline, indicating the sealevel during the better part of the mid-Holocene (see Supplementary Information Fig. 1), the sites cluster into distinct seascapes, two of which appear around Risvåg and Hasvik (Figs. 5 and 6). 
Table 1 Stone age sites on southwestern Sørøya with number of dwellings and sub-area indicated

\begin{tabular}{|c|c|c|c|c|}
\hline No & Site name & Dwellings & New & Sub-area \\
\hline 1 & Sørvær fotballbane & 8 & 1 & Markeila \\
\hline 2 & Årvika & 14 & & \\
\hline 3 & Markeila & 4 & & \\
\hline 4 & Pumpervika Østre & 6 & & \\
\hline 5 & Sandvika & 25 & 4 & Breivik-fjord \\
\hline 6 & Sarset & 11 & 1 & \\
\hline 7 & Bårvik & 4 & & \\
\hline 8 & Mollvika II \# & 2 & 2 & Risvåg \\
\hline 9 & Lille Djupvåg I \# & 1 & 1 & \\
\hline 10 & Lille Djupvåg II & 6 & 5 & \\
\hline 11 & Risvåg & 25 & 2 & \\
\hline 12 & Risvåg østre \# & 4 & 6 & \\
\hline 13 & Hasvåg & 11 & 3 & \\
\hline 14 & Hasvåg Pina \# & 2 & 2 & \\
\hline 15 & Solbakken* & 8 & & Hasvik \\
\hline 16 & Hasvikeidet* & 30 & & \\
\hline 17 & Østre Hasvik* & 10 & & \\
\hline 18 & Store Sandvika \# & 6 & 6 & \\
\hline 19 & Avløysinga V \& M \# & 5 & 5 & \\
\hline 20 & Hollenderbakken & 26 & 3 & \\
\hline 21 & Bårdselven* & 5 & & \\
\hline 22 & Østre Vardhaugsletta* & 4 & & \\
\hline 23 & Korsvika Midtre & 1 & & \\
\hline 24 & Søndre Lauksletta & 2 & 1 & Hasfjord \\
\hline 25 & Lauksletta I & 1 & & \\
\hline 26 & Lauksletta II & 2 & & \\
\hline 27 & Nordre Lauksletta & 12 & 2 & \\
\hline 28 & Taborshamn \# & 31 & 34 & \\
\hline 29 & Jakobbukta \# & 8 & 9 & \\
\hline 30 & Sandvika, Galtefjorden \# & 10 & 10 & Galtenfjord/Dønnesfjord \\
\hline 31 & Makkvika & 23 & 18 & \\
\hline \multirow[t]{2}{*}{32} & Nordøya* & 3 & & \\
\hline & & 310 & 115 & \\
\hline
\end{tabular}

* Individual structures were not georeferenced. \# New site. For site IDs see supplementary information Table 1

At this higher sealevel, Risvåg was a wide bay with several smaller inlets. A total of seven sites and 51 dwellings were in the mid-Holocene situated in this bay with $1200 \mathrm{~m}$ separating the two most distant sites.

A narrow sound located in the modern village of Hasvik at the southern tip of the study region attracted four major sites with at least 74 dwellings. The sites in the central part of this area are all less than $600 \mathrm{~m}$ apart. This is the most disturbed part in the study region, and on the northern side of the sound alone there is local information of an original number 


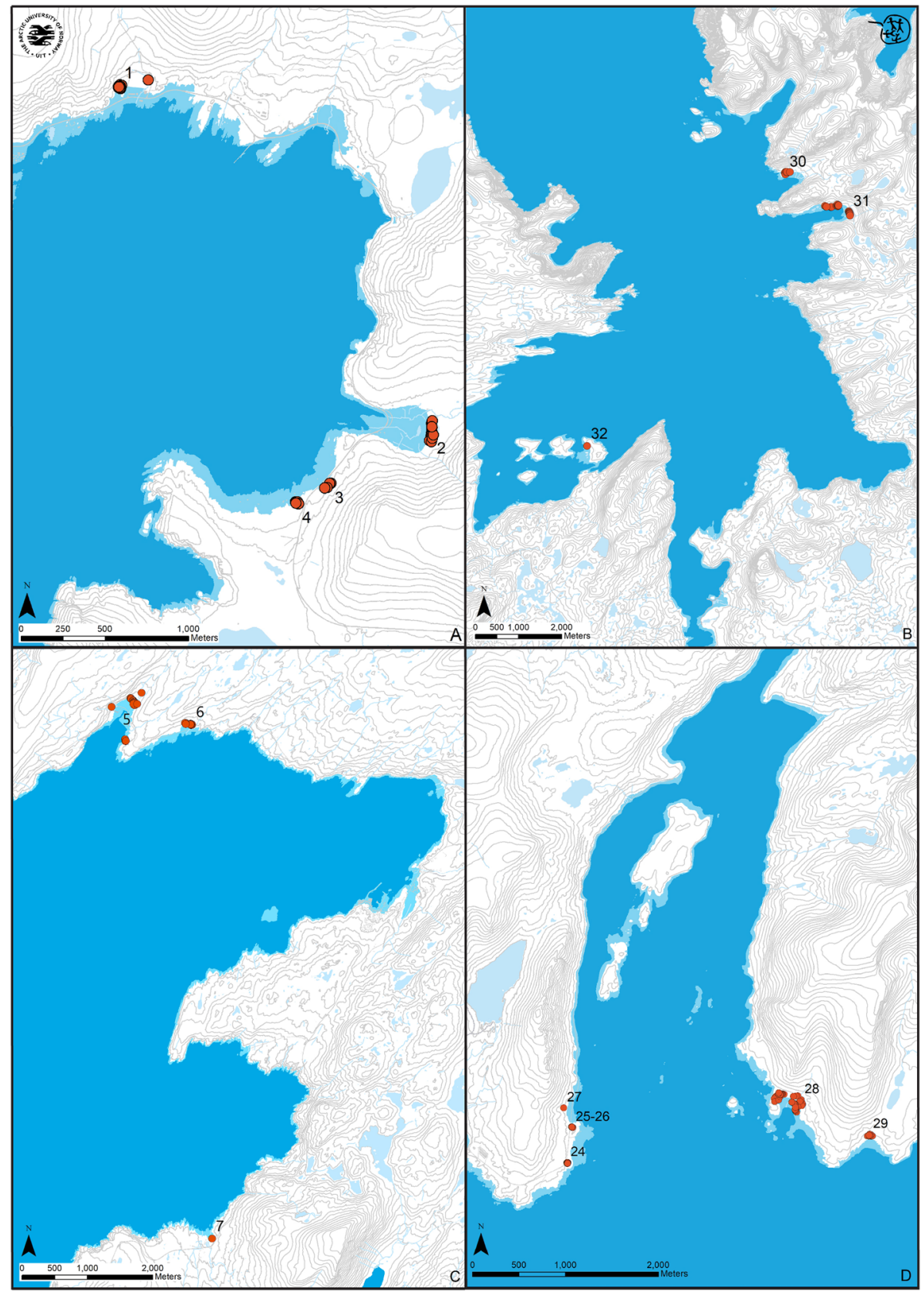

Fig. 4 The subareas Markeila A, Galtenfjord B, Breivikfjord $\mathbf{C}$ and Hasfjord $\mathbf{D}$ with sites. Site numbers according to Table 1. For location of sub-areas see Fig. 3. Sealevels reconstructed at 10 masl. Contour intervals $=20 \mathrm{~m}$. (Illustration: M.S. Lindgren) 
Table 2 Quantitative overview of sites and dwellings in sub-areas

\begin{tabular}{lll}
\hline Sub-areas & No. of sites & No. of dwellings \\
\hline Markeila & 4 & 32 \\
Breivikfjord & 3 & 40 \\
Galtenf./Dønnesfj & 3 & 36 \\
Risvåg & 7 & 51 \\
Hasvik & 9 & 95 \\
Hasfjord & 6 & 56 \\
Total & 32 & 310 \\
\hline
\end{tabular}

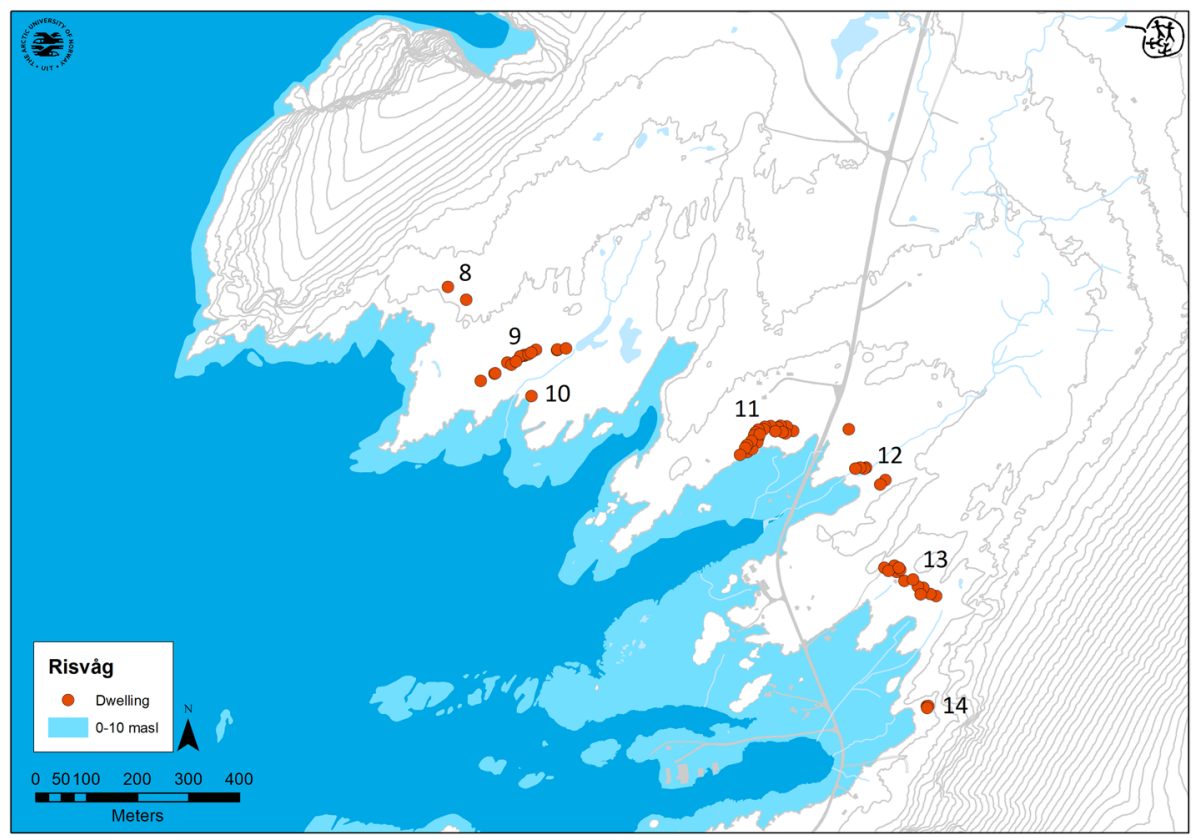

Fig. 5 The Risvåg bay with sites located in coves. Reconstructed seascape at 10 masl Contour inter$\mathrm{val}=10 \mathrm{~m}$. Site numbers refer to Table 1. (Illustrations: G. Skogvold)

of 70 dwellings (Sørensen 1956), which could make the total number as high as c.100. Several other smaller sites are found in the vicinity, adding another 21 dwellings to the larger sub-area. All of these are less than $2 \mathrm{~km}$ from the central sites.

The Risvåg and Hasvik sub-areas are located $2 \mathrm{~km}$ apart in direct line across land or three $\mathrm{km}$ by sea. 146 dwellings of the total 310 , i.e. $47.1 \%$ of all dwellings are found in these two sub-areas.

Finally, the last sub-area with six sites and 56 dwellings is located around the mouth of Hasfjord, east of the Hasvik sub-area. This group includes the large Taborshamn site (Fig. 7) with 31 dwellings. The distance from the centre of the Hasvik sub-area to Taborshamn is $6 \mathrm{~km}$.

It is important to emphasize that not all sites were used contemporaneously. Some sites appear to have been abandoned permanently at an early stage or established late in the period 


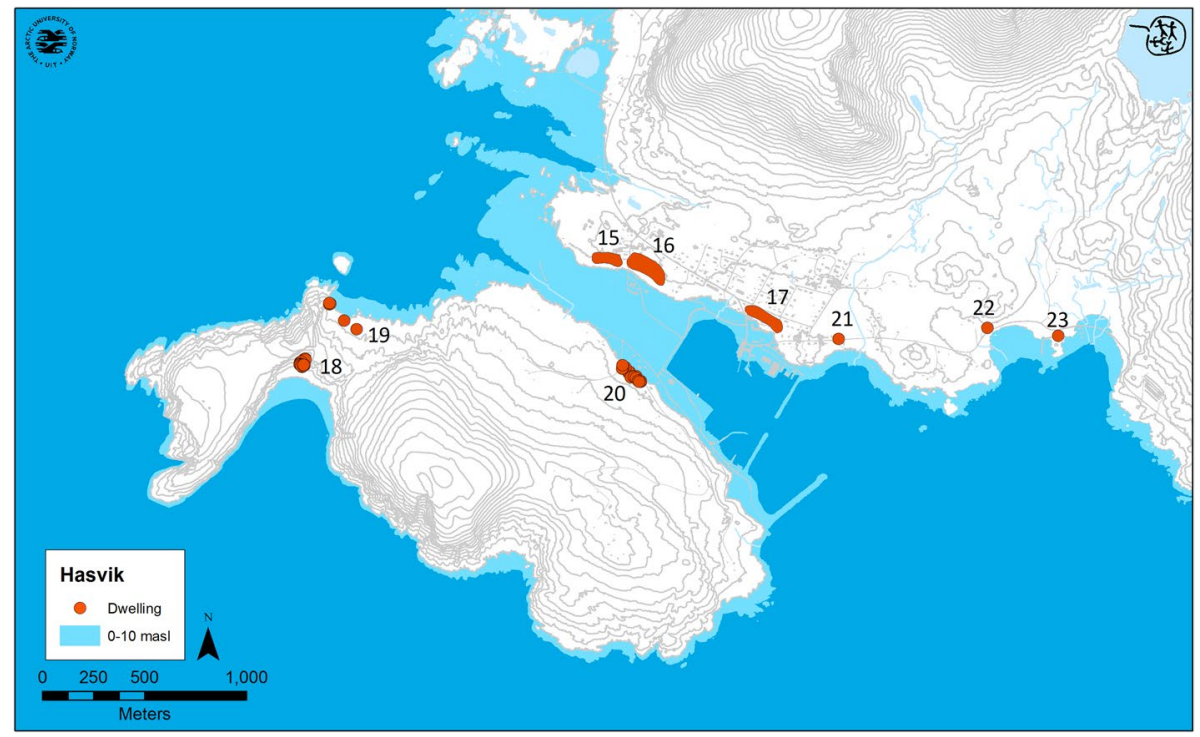

Fig. 6 Hasvik sites in relation to the past narrow sound. Reconstructed seascape at 10 masl Contour inter$\mathrm{val}=10 \mathrm{~m}$. Site numbers refer to Table 1. (Illustrations: G. Skogvold)

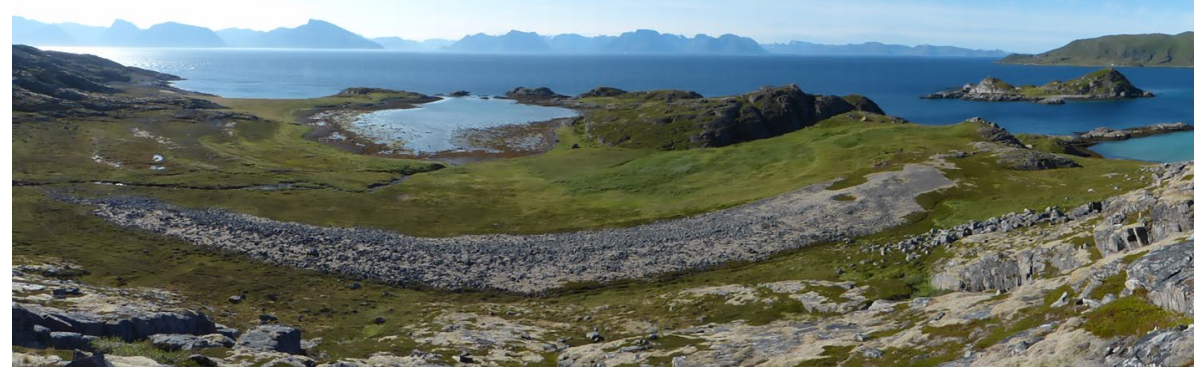

Fig. 7 Panorama of Taborshamn (site 28 in the Hasfjord sub-area) has a natural harbour and extensive views over Sørøysund. The dwellings are located on the beach ridges. (Photo: C. Damm)

of investigation, while others were re-inhabited repeatedly across several millennia. New analyses clearly demonstrate that there would have been few contemporary dwellings at each site (Vollan forthcoming). The number of sites and dwellings in a sub-area does not reflect the past population size directly, but instead indicates that a landscape was attractive over the longterm with coastal foragers returning to the sub-area repeatedly. 


\section{Understanding Topographical Preferences}

In order to understand the active choices behind concrete settlement locations, it was necessary to conduct systematic documentation of the topography at each site. For 30 of the 32 sites in our study region, there is sufficient topographical information for them to be included in a qualitative assessment on site location characteristics (Table 3 and Supplementary Information Table 1).

A key location factor was clearly good landing opportunities for small and light boats, i.e. an open shore with sand, gravel or beach stones, shallow water and/or protection by skerries. However, a few sites appear to lack this. Several of these today has a steep several metres high slope immediately in front of the dwellings, below which there are beach terraces. It is notable that all of these dwellings are located at 19 masl or above, indicating that they are older than the Tapes transgression culminating c.5000 BC. Given that good landing is such a prominent dwelling site feature, it is likely that an original gentler incline

Table 3 Location factors for 30 sites and 297 dwellings

\begin{tabular}{|c|c|c|c|c|}
\hline \multicolumn{5}{|l|}{ Topography } \\
\hline $\begin{array}{l}\text { Small cove } \\
\text { in bay/ } \\
\text { fjord }\end{array}$ & Deep cove in bay & Cove from open sea & Narrow sound & Point \\
\hline 20 & 4 & 2 & 3 & 1 \\
\hline \multicolumn{5}{|l|}{ Landing } \\
\hline Excellent & & Good & & Marginal \\
\hline 11 & & 15 & & 4 \\
\hline \multicolumn{5}{|c|}{ Outlook/monitoring points } \\
\hline Extensive & & Local seascape + viewpoint & Local seascape only & Restricted \\
\hline 12 & & 11 & 6 & 1 \\
\hline \multicolumn{5}{|c|}{ Orientation: sites/dwellings } \\
\hline E-SE & $\mathrm{S}$ & SW & W & N-NW \\
\hline $9 / 99$ & $10 / 118$ & $4 / 19$ & $1 / 14$ & $6 / 47$ \\
\hline
\end{tabular}

Protection/exposure weather

\begin{tabular}{lll}
\hline Protected & Exposed & Highly exposed \\
24 & 5 & 1
\end{tabular}

Fresh water

\begin{tabular}{lll}
\hline Brook 1st (year round) & Brook 2nd (seasonal restrictions) & No (more than 300 m away) \\
7 & 8 & 15 \\
\hline
\end{tabular}

Access to other resource areas

\begin{tabular}{llll}
\hline Excellent & Good & Limited & None \\
4 & 10 & 13 & 3 \\
\hline
\end{tabular}

For details see supplementary information Table 1 


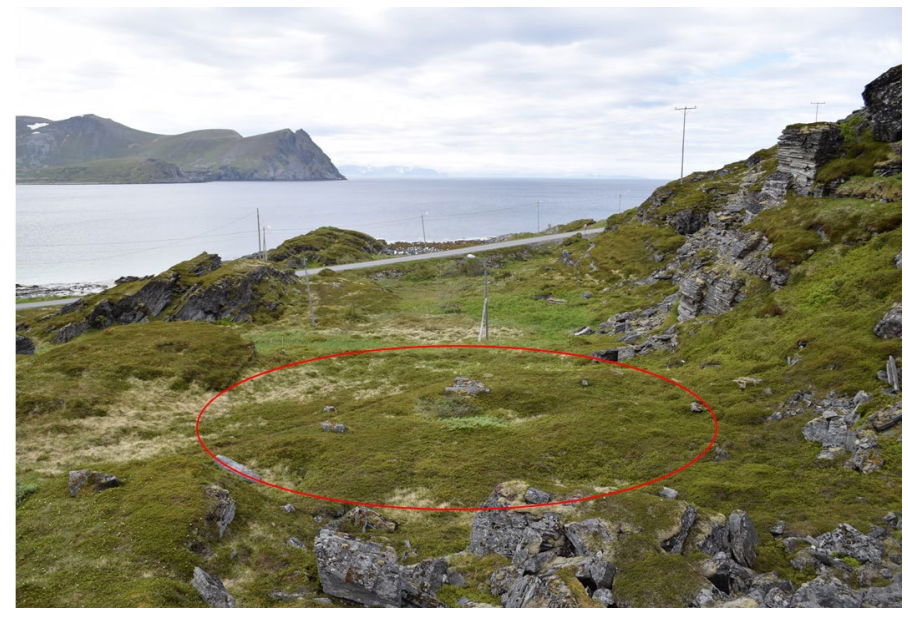

Fig. 8 Many sites are located in narrow coves protected by cliffsides and rocky outcrops, but may still command good views of the seascape. Sørvær fotballbane, site 1 in the Markeila sub-area. Area with dwellings encircled. (Photo: C. Damm)

in front of them eroded away during the transgression, and that they originally had better landing access.

Nearly all sites were located in coves within their local seascape. Twenty were located in small coves, often tucked in between rocky outcrops (Fig. 8). Others are located in deeper coves with higher cliffsides to at least one side, and a few in a narrow sound. Only one site is located on a headland. As noted initially, there is a positive association between well-drained sediments and dwelling remains, and such sediments are often, but not exclusively, found in coves. This undoubtedly contributes towards the preference for coves, but well-drained sediments are also found on straight coastlines and small promontories, where sediments were caught between rocky outcrops.

Despite the preference for coves within local seascapes, it is striking that many sites command extensive views characterized with sightlines that extend beyond the local seascape and out onto open sea and across to other land areas (see Fig. 7 and 8). Close to half the sites have such extensive outlook from the site itself. Another 11 have good views of their local seascape, but in addition have a monitoring point with extensive view accessible within short distance from the dwelling site.

The majority of sites face southeast, south or southwest. This is partly a result of the general orientation of the study region, but the limited number of sites facing north or west may be linked to a preference for protection from the prevailing western and northwesterly winds. The location in coves and the dominant orientation away from north and northwest orientation makes most of the sites well-protected from harsh weather. It is also typical that on sites with a more extensive dwellable area, i.e. where suitable terrain would have allowed more dwellings, the structures are located only on the leeside of the cove. Thus, at many sites, dwellings cluster under outcrops and cliffsides protecting them from western and northern winds. One site only is located in a highly exposed position, on the tip of a headland with no protecting outcrops. 
Half of the sites do not have immediate access to fresh water, defined as within $300 \mathrm{~m}$. The brooks in the remaining half are divided into 1st and 2nd order brooks, where 1 st order brooks are larger and permanent, while 2 nd order brooks are smaller and could run dry in summer or freeze up in winter. Although the size of the brooks may be climate dependent, the local topography determines their location and have not altered since the mid-Holocene.

The 10 sites in the three northernmost sub-areas have short $\left(<1 \frac{1 / 2}{2}\right.$ hours $)$ and easy walks for getting onto the plateau and for reaching bays on the outer side, where alternative resources were available. The travel distance is generally much further for the sites in the three southern sub-areas.

In each sub-area, we find that a few sites appear to have been particularly attractive. These have many dwelling remains and based on inventory, radiocarbon dates and height

Table 4 The documented site qualities ordered according to landing conditions

\begin{tabular}{|c|c|c|c|c|c|c|}
\hline & Site name & Dwellings & Landing & Seascape & Fresh water & Outlook \\
\hline 28 & Taborshamn & 31 & Excellent & $\begin{array}{l}\text { Deep cove from open } \\
\text { sea }\end{array}$ & Brook 2nd & Extensive \\
\hline 16 & Hasvikeidet & 30 & Excellent & Narrow sound & No & Local seascape + \\
\hline 11 & Risvåg & 29 & Excellent & Small cove in bay & Brook 1st & Local seascape + \\
\hline 20 & Hollenderbakken & 26 & Excellent & Narrow sound & No & Local seascape \\
\hline 31 & Makkvika & 23 & Excellent & Deep cove in bay & Brook 2nd & Local seascape \\
\hline 5 & Sandvika & 23 & Excellent & Deep cove in bay & Brook 1st & Local seascape + \\
\hline 2 & Årvika & 14 & Excellent & Deep cove in bay & Brook 1st & Restricted \\
\hline 30 & Sandvika Galtenfjord & 10 & Excellent & Cove in bay & Brook 2nd & Local seascape + \\
\hline 15 & Solbakken & 8 & Excellent & Narrow sound & No & Local seascape + \\
\hline 13 & Hasvåg & 11 & Excellent & Small cove in bay & Brook 1st & Local seascape + \\
\hline 12 & Risvåg Østre & 4 & Excellent & Small cove in bay & Brook 1st & Local seascape + \\
\hline 27 & Nordre Lauksletta & 12 & Good & Small cove in fjord & No & Extensive \\
\hline 6 & Sarset & 11 & Good & Small cove in bay & Brook 2nd & Local seascape + \\
\hline 1 & Sørvær fotballbane & 8 & Good & Small cove in bay & Brook 2nd & Extensive \\
\hline 29 & Jakobbukta & 8 & Good & Cove from open sea & No & Extensive \\
\hline 10 & Lille Djupvåg II & 6 & Good & Small cove in bay & Brook 2nd & Extensive \\
\hline 4 & Pumpervika & 6 & Good & Small cove in bay & No & Local seascape \\
\hline 21 & Bårdselven & 5 & Good & Cove in bay & Brook 2nd & Extensive \\
\hline 22 & $\emptyset$ stre Vardhaugsletta & 4 & Good & Cove in bay & No & Extensive \\
\hline 7 & Bårvik & 4 & Good & Small cove in bay & Brook 1st & Local seascape \\
\hline 8 & Mollvika II & 2 & Good & Small cove in bay & No & Extensive \\
\hline 14 & Hasvåg Pina & 2 & Good & Small cove in bay & No & Local seascape + \\
\hline 26 & Lauksletta II & 2 & Good & Small cove in fjord & No & Local seascape + \\
\hline 9 & Lille Djupvåg I & 1 & Good & Small cove in bay & Brook 2nd & Extensive \\
\hline 25 & Lauksletta I & 1 & Good & Small cove in fjord & No & Extensive \\
\hline 23 & Korsvika Midtre & 1 & Good & Small cove in bay & Brook 1st & Local seascape + \\
\hline 18 & Store Sandvika & 6 & Marginal & Small cove in bay & No & Extensive \\
\hline 3 & Markeila & 4 & Marginal & Small cove in bay & No & Local seascape \\
\hline 19 & Avløysinga V & 3 & Marginal & Small cove in bay & No & Local seascape \\
\hline 24 & Søndre Lauksletta & 2 & Marginal & Point & No & Extensive \\
\hline
\end{tabular}


above sealevel from similar excavated sites elsewhere on Sørøya, it is evident that such sites were used and re-visited repeatedly over centuries and even millennia. These sites score high on the most important site location factors, i.e. excellent landing, protected location, good outlook and fresh water. Good landing in particular appears to be a key factor for repeated habitation, as nearly all sites with 10 or more dwellings have excellent landing (Table 4). Most, but not all, have outlook beyond their local seascape from or close to the site itself. On the other hand, in only a few cases are other sites visible, even from nearby viewpoints. Intervisibility between sites was not a relevant factor in the area.

To summarize, good landing, easy monitoring of surroundings and shelter appear to be the most prominent factors attracting coastal foragers in the mid-Holocene. This is supported also by the survey of areas with no sites. Beach ridges and coves facing directly north and west often have limited habitation (e.g. the extensive beach terraces on the southern side of the Markeila bay west of site 4 (Fig. 4A) and the limited number of dwellings on large northfacing terraces at site 19 in the Hasvik sub-area (Fig. 6), from where there is limited outlook and exposure to northern winds). Furthermore, there are rarely sites in the deeper part of the fjords, where outlook is limited (e.g. Dønnesfjord and Hasfjord subareas). Landing conditions at the head of Breivikfjord were problematic due to exposure to westerly winds (the current settlement only expanded when a modern quay was built) and rather than inhabit the small promontories in Risvåg, all dwellings are found in coves (Fig. 5).

\section{Evaluating Resource Availability}

Having established patterns in settlement distribution and location, we proceeded to consider resource availability in order to discuss their impact on settlement strategies. Which resources were available, and to what extent do they fluctuate geographically and seasonally?

The excavated material from mid-Holocene sites in eastern Finnmark demonstrates that fishing and sealing dominated the subsistence with cod in all cases being most prominent, followed by haddock and pollock. The exploitation of seal and dolphin species varied due to local availability and auk dominated among the birds. Reindeer and elk constitute a very small part of the material (E. Helskog 1983; Engelstad 1984; Renouf 1989; Hodgetts 2010). Hunting and fishing of identifiable species such as reindeer, elk, bear and halibut is also documented in the mid-Holocene rock art in western Finnmark (Gjerde 2010; Helskog 2014). There is very good correspondence between the present species and evidence from mid-Holocene osteological data and rock art. Accepting that the ecology of the species was the same in the past, particularly as the maritime landscape has remained much the same, we may assume that the species available and exploited in the mid-Holocene did not differ from the present ones, although fluctuation in quantities may have occurred due to climatic variation.

The mid-Holocene human skeletal material from Northern Norway is sparse. At present, there is only isotope analyses from one individual $400 \mathrm{~km}$ south of the study region, dated to 4000-3714 BC, and indicating a strong maritime diet at a high trophic level, suggesting that seal or possibly cod constituted the main part of the diet. (Günther et al. 2018).

As there is no osteological material from our study region, we here rely on a presentation of the most prominent present and historically documented resources (Fig. 9), based on information from reports on historical land use and catchment (Myrvoll et al. 2011; 


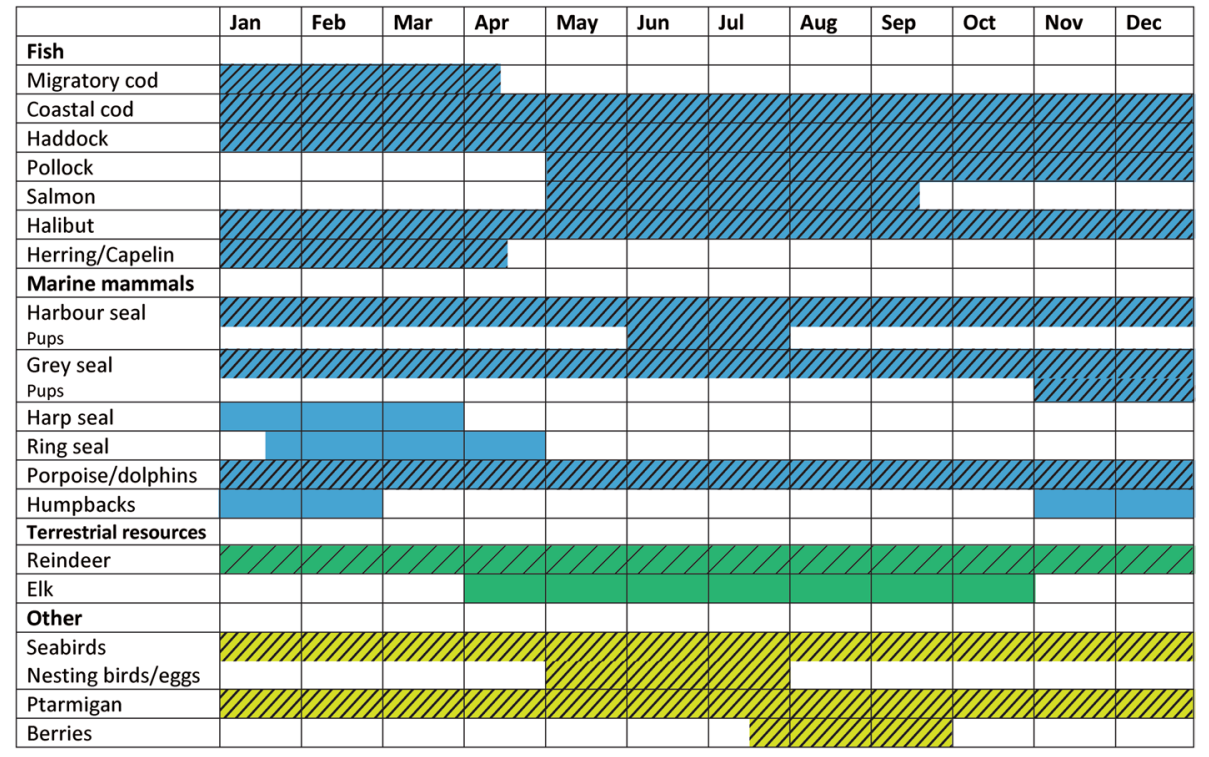

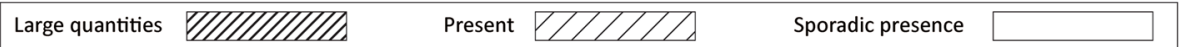

Fig. 9 Overview of main subsistence resources and their seasonality

Henriksen 2021), from national databases on species observation (Norwegian Biodiversity Centre), and online records of ecology and habitats for fish, birds and mammals (Institute of Marine Research; Norwegian Polar Institute).

As is typical in many high latitude areas (see also Rowley-Conwy 1999), the resource availability on and near Sørøya is characterized by a low diversity of species, some of which are which seasonal, but typically present in large quantities. Marine resources dominate the species list, despite Sørøya being a large island. In a wider circumpolar context, the marine productivity at Sørøya stands out as high practically all year round, whereas many other regions face more marked fluctuation with affluent and lean resource seasons.

\section{Fish}

While the winter and early spring would have been particularly rich seasons for fishing in the study region, there would have been ample fish resources in all seasons.

Among the resources present at Sørøya today, the migratory winter cod is particularly significant. It arrives from the Barents Sea to spawn on the Norwegian coast from January to April (Norwegian Polar Institute). Southwestern Sørøya is historically one of the two main places where boat crews would gather to harvest this resource. While ocean temperatures may have been higher in the early mid-Holocene, this did probably not impact negatively on presence of the migrating cod. It may have led to a slightly more northerly presence of the capelin and hence also the cod (Ólafsdóttir et al. 2017). It is possible that the spawning area near Sørøya would have been even more attractive during the Holocene maximum if the present main spawning ground near Lofoten, $400 \mathrm{~km}$ to the south, were relocated further north. According to local information, migrating cod would come 
very close to shore before the recent downturn of the fisheries. The coastal cod is available throughout the year, and there used to be much of it. Breivikfjord is a well-known spawning ground for both migrating and coastal cod, but the coastal cod is found widely in all fjords and bays. According to the locals, the conditions for wind drying of fish for preservation are good from October to April/May.

Haddock spawns on the outer side of Sørøya from March to June but is widely present year-round in the region. Summer and autumn shoals of pollock are plentiful in Northern Norway. Another prominent species is the halibut, which is the only identifiable fish species featured in the rock art. Young individuals are found in more shallow areas close to the coast, while older ones are deep sea fish.

Salmon migrates into the area and can be caught May-September. The only salmon river on Sørøya is located at the head of Breivikfjord (Myrvoll et al. 2011:132-133). Salmon sea-fishing (in contrast to river fishing) is prominent in our study region with Breivikfjord being a favoured area (Myrvoll et al. 2011:137, Henriksen 2021). Sea trout and Arctic char may be found in a few rivers and lakes, but on Sørøya the majority of the lakes with trout is a result of cultivation, in particular from the 1860s onwards (Myrvoll et al. 2011:132).

\section{Marine mammals}

Medieval records refer to extensive seal hunting around Sørøya (Andreassen and Bratrein, 2011:319). Known seal species in the region today are Harbour seal and Grey seal, both stationary (Institute of Marine Research). The gregarious Grey seal, found in large colonies, prefers outer, exposed skerries and is common on the outer side of Sørøya, although it is observed in the entire study region and into the mainland fjords. The Harbour seal in contrast prefers more sheltered areas in fjords, where groups bask on skerries and sand banks. Migrating Harp seals may visit the coast during winter. The ice-dependent Ring seal is not common in western Finnmark today, but sightings do occur (Norwegian Biodiversity Centre). The sea and fjords around Sørøya do not freeze in winter, but ice may settle for a month or so in the innermost parts of the fjords, including Hasfjord. Harbour porpoise and Atlantic white sided dolphins are common. All of these species are known from middens elsewhere in Finnmark (E. Helskog 1983; Engelstad 1984; Renouf 1989; Hodgetts 2010).

Capelin and herring attract whales and today humpbacks and orcas are found along the coast from November to March. However, the location of the latter is unpredictable as the migrating patterns of the herring fluctuate. The evidence for whale hunting in Stone Age northernmost Norway is sparse, but present, with small amounts of whale bones found in middens. One bone from a Gray whale has a tip of a slate point lodged in it (Nikola Kovačević pers.com.).

It is likely that Harbour seal, Grey seal, porpoises and dolphins were stable all year resources hunted for a variety of purposes (blubber, skin, meat), while other species may have been caught on a more sporadic basis.

\section{Terrestrial Mammals}

Only a few terrestrial mammals would have been found on the island. In northernmost Norway, reindeer is likely also in the past to have migrated from lowland and interior winter habitation areas towards the coast and higher ground in the summer to avoid the many insects. Both reindeer and elk will swim across Sørøysund, and it is likely that reindeer 
roamed the island, either during summer, or possibly as an all-year population. The presence of elk on Sørøya is presently sporadic but may have been more frequent during the Holocene maximum when the vegetation was more extensive. Sørøya never had any terrestrial predators such as fox, bear, lynx, wolf or wolverine, which are otherwise common in the larger region.

\section{Birds, Plants and Other Resources}

Bird cliffs with particularly kittiwakes and auks are likely to have been popular for their eggs. Such colonies are today most numerous on the outer coast (Myrvoll et al. 2011:143). Ptarmigan were likely bountiful. Auks are common in middens and capture of large birds with small wings, likely the extinct Great auk or maulting geese are depicted in the Alta rock art. While birds and eggs provided a welcome variation in the diet it is unlikely that they played a major role in the subsistence.

Berries of various sorts (blue berries, cloud berries, crowberries, lingonberries) have always been a valued resource, as were various plants for food, medicine or other use. Large trees, possibly required for construction of dwellings, were uncommon. However, driftwood would have been present. Today large quantities are found on the outer side of the island, but present also elsewhere.

The acquisition of lithic raw materials is also relevant for mobility patterns. Quartz is common on the island, and one prehistoric quartz quarry was discovered during the survey. Beach nodules of other raw materials were also available, but more substantial quarries for chert and slate, the raw materials most used in the mid-Holocene, were located further into the mainland fjords.

\section{Seasonality}

The study region is clearly dominated by marine resources. Some key species, such as the migrating cod, pollock and salmon, are seasonal, whereas others such as the coastal cod, haddock, halibut and several seal species are found year-round.

The most resource rich period would have been from January when the migrating cod arrives through early summer with the arrival of salmon, pollock, nesting seabirds and Harbour seal pups. The autumn and early winter months from late September to early January are likely to have been the most resource sparse, with the summer season species gone and before the arrival of the migrating cod. Nevertheless, the coastal cod was a reliable year-round resource.

Subsistence resources were abundant in the study region, but some resources were perhaps acquired from further afield, either through relocation or by exchange. Hides for various purposes were particularly important (Skandfer forthcoming). While seal skins would have been valued for skin boats and could be used for tents and clothing, reindeer hides are superior for garments. In the larger western Finnmark region, it is likely that reindeer hunting was a seasonal activity best undertaken during the late summer-early autumn migration from the coast to the inland tundra. Smaller fur-providing animals may have been valued for adornment, bags and smaller clothing items, but apart from sea otters none are found on Sørøya, nor any fur-bearing predators. Rich salmon rivers are found in the mainland fjords, most notably the Alta river, c.80 km from the study region. This is also where the main rock art sites are located. Since salmon are available in the rivers from May-June to late summer and the reindeer at their fattest and with 
best hide in late summer and early autumn, it is possible that seasonal relocation from the Sørøya area to the mainland fjords and adjacent inland took place late summer and early autumn. Dried and stored meat from the reindeer and possibly elk hunt could also have contributed to the more meagre late autumn-early winter months, together with dried fish.

\section{Reconstructing Settlement and Foraging Patterns on Southwestern Sørøya}

Previous studies have noted that mid-Holocene sites in northernmost Norway were located in fjords and sounds with more limited exploitation of the outer coast. Schanche (1994) pointed out sub-area clustering in Varanger, eastern Finnmark for the centuries around $2000 \mathrm{cal}$. BC, and linked this to separate social group territories, possibly with different mobility patterns as supported by faunal analyses (Hodgetts 2010). It seems otherwise tacitly assumed that sites were rather evenly distributed. In existing literature, the southwestern part of Sørøya has not been prominent, and the general impression has been that Stone Age groups favoured areas in the Sørøysund proper and other less exposed areas. It has been argued that sites on the outer side of Sørøya are small and that these were shortterm specialized spring catchment sites and a late (post 2000 BC) phenomenon (Simonsen 1979:414; Andreassen 1984:238).

Our investigations demonstrate that southwestern Sørøya with more than 300 Stone Age dwellings was as densely settled as any other region in western Finnmark. The attraction of the region was the availability of marine resources which is high practically round the year, and particularly from January to July. While our surveys have not been as intensive in other parts of the Sørøysund region, the preliminary results suggest that significant clustering to delimited seascapes and similar site location preferences prevail also beyond southwestern Sørøya.

The spatial distribution demonstrates that the sites were not simply evenly distributed, but closely linked to maritime landscapes, best described as distinct local seascapes: bays, fjords and sounds. The Hasvik sound area has the highest density of dwellings. The sheltered location and easy boat access to both west and east made the area very attractive. With two other sub-areas nearby, Risvåg and Hasfjord, this southern part of the study region has a very high overall density of sites and dwellings. The three northern Sub-areas, Markeila, Breivikfjord and Galtenfjord have fewer sites and dwellings, but still more than one third of all dwellings are found here, giving evidence for extensive settlement also in these most exposed areas.

Within each of the sub-areas, habitation sites were carefully selected with priority given to good landing, monitoring points and shelter, while fresh water was of secondary importance.

The six sub-areas all had access to sufficient resources on a year-round basis, but map onto local resources slightly differently. Fishing appears to be the dominant staple resource in all areas, but several had access also to alternative resources, in particular seal and birds, but also reindeer.

Starting in the north, the two bays Markeila and Breivikfjord are spawning areas for the migrating cod, but are important areas also for other fish species, including coastal cod and salmon. From the sites in these two landscapes there are short distances to the inland plateau with ptarmigan and reindeer, but in particular to the outer coast where grey seal and 
bird cliffs are more common. Here there are several protected wide sandy coves. Sanddrift cover the beaches and any prehistoric activity, but cultural layers in a rock shelter were radiocarbon dated to the first-century AD (Skandfer et al. 2020).

Historically Breivikfjord was known as the most important area for the winter fishing. When the season ended in the spring, the fishers relocated to Galtenfjord opening on to the outer coast for the haddock fishing (see Figs. 3 and 4). The western side of Galtenfjord had no sites in the coves, but hosted bird colonies, skerries and headlands that should attract seals, notably the large Grey seal. The seascape outside the fjord is hard to navigate due to strong currents and waves, but from the sites there is access to the plateau, where there are shooting blinds for reindeer hunting. Contrary to earlier interpretations, the significant number of dwellings in Galtenfjord suggests that the resources on the outer coast were exploited throughout the mid-Holocene.

The three northern sub-areas map rather directly onto key seasonal resources, in particular the winter fishing for migrating cod, but also distinguish themselves by short distance access to alternative areas and resources, marine and terrestrial. They would all have allowed the inhabitants to fish predominantly in their local seascapes, without forcing them onto open sea.

Moving on to the southern sub-areas, many different fishing grounds are located within 3-4 km from the sites in the Risvåg, Hasvik and Hasfjord sub-areas. From the sites in the narrow sound in the Hasvik group, there is $2.5 \mathrm{~km}$ to the closest good fishing grounds to the east. To the west, there is good halibut fishing. From the larger sites in the Hasfjord sub-area, there is less than $2 \mathrm{~km}$ to fishing grounds just outside the mouth of Hasfjord. The many small islands and skerries here were optimal for the Harbour seal to rest. From Taborshamn, there is direct access to a rich ptarmigan habitat and shooting blinds for reindeer on the Tabor mountain. However, from most of the sites in these three sub-areas exploitation of inland resources or travels to the outer coast would have started with short boat journeys to reach landings with easier traverse access.

The three southern sub-areas had good access to a variety of fish species within shorter distances by boat. While coastal cod and pollock were available near shore, the main fishing grounds would require venturing out on the open sea. Harbour seal and porpoises could also be found, but in comparison with the northern sub-areas access to alternative resource areas in many cases required longer travel distances if not settlement relocation.

\section{Comparative Perspectives}

Our survey data enabled us to identify patterns in spatial distribution, in site preferences and their association with local resource availability on southwestern Sørøya. However, given the rugged topography of the region with limited habitable areas, the question remains whether these patterns are simply determined by the geographic constraints or whether alternative patterns of occupation were potentially possible. To address this issue, we examined the early Holocene habitation patterns from Northern Norway.

\section{Comparison with Early Holocene Pioneer Settlement Patterns in Northern Norway}

Bjerck's studies $(1989,1990)$ of early Holocene settlement patterns in the Vega archipelago $700 \mathrm{~km}$ south of Sørøya has served as a template for similar investigations in northernmost 
Norway (Barlindhaug 1996; Grydeland 2000). His extensive surveys of early Holocene sites revealed that residential sites were located on well-drained sediments, including pebbled beaches, on flat or gently sloping terrain and were protected from strong winds. The sites dating 8000-4000 BC were strongly associated with safe harbours and were close to resources at tidal currents, headlands and fishing grounds. Fresh water was frequently absent at the sites. Areas with no sites deviated from this pattern, notably lacking good harbours (Bjerck 1989:141).

Likewise, studies of the pioneer settlement (9500-8000 BC) in Finnmark have noted that such early Holocene sites had an even stronger association with exposed necks of lands/isthmuses or small islands with landing possibilities from several directions (Olsen 1994:38). An analysis of 25 pioneer sites, primarily lithic scatters without dwellings, around Troms $\emptyset 150 \mathrm{~km}$ south of our study region (Table 5) demonstrated a preference for sites in rather exposed locations such as headland, isthmuses and islets with several natural landing sites and good outlook (Barlindhaug 1996).

These studies show that landing has been of utmost importance throughout the Stone Age, but that in the early Holocene this was to a greater extent resolved by a preference for highly exposed sites with access from several directions, often located on headlands, isthmuses and islets rather than sheltered location. In contrast, nearly all our mid-Holocene sites are located in sheltered coves. However, sites from all periods appear to have been chosen for good vantage points.

While landing and monitoring are key factors in both the early and the mid-Holocene, the concrete choices in site location differ markedly despite similar geography. However, the availability of strandflats and beach ridges would have been more limited in the early Holocene, as these were established through isostatic uplift and transgression. The transgression may in some areas have flooded and destroyed early Holocene settlements in

Table 5 Location factors for 25 pioneer sites

Topography

\begin{tabular}{lllll}
\hline Isthmus & Islet & Straight coastline & Bay/cove & Headland \\
2 & 2 & 3 & 5 & 13 \\
\hline
\end{tabular}

Local seascape $\sum 45$

\begin{tabular}{llll}
\hline Open sea & Fjord & Sound & Shallow water \\
4 & 15 & 20 & 6 \\
\hline
\end{tabular}

Number of harbours

\begin{tabular}{lll}
\hline 1 & 2 & 3 \\
7 & 15 & 3 \\
\hline
\end{tabular}

Protection/exposure

\begin{tabular}{llll}
\hline Highly exposed & Exposed & Protected \\
7 & 13 & 5 \\
\hline Outlook & & & \\
\hline $50-100^{\circ}$ & $100-200^{\circ}$ & $200-300^{\circ}$ & $300-400^{\circ}$ \\
5 & 14 & 4 & 2 \\
\hline
\end{tabular}

Based on Barlindhaug 1996 
protected locations. While the data may therefore be biased in favour of more exposed early locations, the near absence of such in the mid-Holocene is clear. Possible strategic backgrounds for the difference between early and mid-Holocene sites will be discussed below.

\section{Circumpolar Comparisons}

The comparison between early and mid-Holocene site locations in northernmost Norway suggests that by the mid-Holocene the landscape was occupied differently. To address whether the latter was a unique pattern for northernmost Norway or a more common strategy in the circumpolar zone, we move further afield to similar geographical environments. As our study region, Newfoundland and the Aleutian Islands on the east and west coast of North America, respectively, are characterized by rich marine ecosystems, rugged coastal topography, sparse vegetation and harsh weather. Contrary to Northern Norway and the Aleutians, parts of Newfoundland experience sea ice during the winter. The overall topographical similarities will allow us to discuss in more detail what drives the patterns observed in our study region. Explicit regional analyses of past foraging sites in the circumpolar region are sparse and the examples included here focus on site location, rather than spatial distribution.

At Newfoundland, Canada, an analysis of the location of 80 Late Maritime Archaic Indian sites (3500-1200 BC) was performed by Bell and Renouf (2004) (Table 6). None of the sites have dwelling structures and the authors interpret this to reflect less intensive occupations. The majority of the sites were located on the coast and concentrated to areas with high marine productivity close to the shore. $71 \%$ were found in nearshore locations, defined as sheltered coastal areas oriented towards land, while a considerably smaller number were on exposed areas towards the open sea. The latter may be associated with sealing during winter when harp seals are found on the drift ice and harbour seal away from the ice packed bays (Tuck \& Pastore 1985). Nearshore sites were linked to a variety of marine,

Table 6 Location factors for Late Maritime Archaic sites, Newfoundland. Based on Bell \& Renouf 2004, Table 2

\begin{tabular}{|c|c|c|c|c|}
\hline \multicolumn{2}{|l|}{ Coastal } & \multicolumn{3}{|l|}{ Interior } \\
\hline $84 \%$ & & $16 \%$ & & $\sum 80$ sites \\
\hline Offshore & Nearshore & Near interior & Deep interior & \\
\hline \multirow[t]{2}{*}{$13 \%$} & $71 \%$ & $7 \%$ & $9 \%$ & $\sum 80$ sites \\
\hline & Deep bays and arms & & & \\
\hline Head & Mid & Mouth & & \\
\hline $36 \%$ & $48 \%$ & $16 \%$ & & $\sum 25$ sites \\
\hline \multicolumn{5}{|c|}{ Shore line setting } \\
\hline Cove & Point & Straight & & \\
\hline $63 \%$ & $21 \%$ & $16 \%$ & & $\sum 67$ sites \\
\hline \multicolumn{5}{|c|}{ Topographical preferences } \\
\hline $\begin{array}{l}\text { Near moni- } \\
\text { toring } \\
\text { point }\end{array}$ & View in more than one direction & Near stream or pond & On route inland & $\begin{array}{l}\text { (more than one } \\
\text { preference pr } \\
\text { site possible) }\end{array}$ \\
\hline $70 \%$ & $46 \%$ & $89 \%$ & $21 \%$ & \\
\hline
\end{tabular}


riverine and terrestrial resources. $63 \%$ of the coastal sites were located in coves, although a good number were found on points and on straight coastlines. Many sites had views in more than one direction and a good monitoring station in the vicinity. $89 \%$ had fresh water nearby and $21 \%$ were located at good routes for journeys inland to other types of resources such as caribou hunting.

Surveys from the Aleutian Island in Alaska point to many of the same location factors as in our study region (Turner 1970:112-113, 119-121; Martinson 1973:142-144; McCartney 1977; Frohlich 2002). Unfortunately, the surveys do not discern between different chronozones, but based on excavated sites there appear to be little chronological variation. Sites are almost exclusively represented by remains of semi-subterranean dwellings.

At Adak, Frohlich identified several settlement concentrations with some sites away from these. A few short inland passes connect the different clusters (Frohlich 2002:83). Key elements in site location for the Aleutians more widely were protected landing, good outlook, well-drained sediments for the semi-subterranean dwellings, fresh water and closeness to resources. The importance of protected landings, typically in coves and often with reefs or islets in front to abate waves, is stressed repeatedly.

Sites are located on lookout places to spot sea mammals, friends and enemies. If a site does not offer good observation from the dwelling area, nearly all have a good observation spot in close vicinity. Defensibility and the emphasis on spotting enemies was relevant in the context of raiding known from the region (Maschner and Reedy-Maschner 1998).

Proximity to local resources is mentioned as a factor (Martinson 1973; Johnson 1992), although with the exception that sites appear not to be located close to sea mammal rookeries (Turner 1970; McCartney 1977:73), as the animals tend to be weary and may relocate if disturbed frequently.

Fresh water was usually found in the vicinity but did sometimes require a short boat trip. Despite the lack of trees on the islands, driftwood does not appear to have been a factor in site location preferences (Turner 1970).

\section{Summary of Comparative Insights}

While the early Holocene sites in Northern Norway showed deviation in location preferences compared to our study, there is significant correspondence between our mid-Holocene sites, the Late Maritime Archaic sites on Newfoundland and sites in the Aleutians. Good landing and protected harbours were the most important factors in the investigated coastal environments. The active choice of coves for settlements is a preference in all three cases.

A good outlook over the surrounding seascape allowing the inhabitants to easily observe weather conditions, to monitor arrivals and by-passers, to register birds indicating major shoals of fish and to spot sea mammals is also a primary factor.

Higher preference for site locations on headland, points and islets may be associated with sealing, and perhaps in particular migratory species, as is the case on Newfoundland, and possibly for early Holocene Norway (Bjerck et al. 2016; Bjerck 2017). This has also been noted for example for the Labrador coast (Fitzhugh 1978). 


\section{Discussion}

The present study aimed first of all to identify the choices and strategies that lay behind mid-Holocene settlement patterns in northernmost Norway. This required generation of a robust new data set through extensive field surveys combined with evaluation of other available sources. The rugged coastline and high cliffs caused topographical constraints, but not to an extent that excluded human choices. Additionally, the study sought to address the extent to which these patterns differed from earlier periods in the broader region and query any broader circumpolar mid-Holocene parallels.

The study demonstrates that on Southwestern Sørøya settlements were distributed in distinct local seascapes, often with stretches of rugged un-inhabitable coastline in between. Nevertheless, our emphasis on mapping both presence and absence of sites clearly show that site location was not forced by the geography, but that active choices were made when selecting locations to establish and maintain create dwellings. The research shows that the main factors informing these decisions were good landing conditions and monitoring points followed by shelter from prevailing winds. Indeed, dwellings often cluster tightly in the leeside of a ridge or in tiny coves with little additional activity area, whereas exposed north- and west-oriented beach ridges and headlands were avoided.

Fresh water was not a definitive factor. It was required for drinking but needed in limited amounts only for anything else. Fish may for example be cooked in sea water, and it is likely that the diet was otherwise dominated by fermented or dried foods (Damm 2021). During winter snow could be melted to meet the requirements. In other seasons, fresh water was obtained in other manners. On the American Northwest coast, Ames suggest that at some summer sites water was ferried in (Ames 2002:44). Similarly, at a historical island summer base for Sami fresh water had to be brought from the neighbouring mainland, at least $3 \mathrm{~km}$ away, alternatively from a neighbouring island, and in the Baltic skerries rainwater had to be collected, as other sources were too distant.

In all sub-areas, there is at least one site with more than ten dwellings. It is evident from Table 4 that these are sites with the most favourable location factors: excellent landing, shelter, access to monitoring points and often fresh water. The larger number of dwellings indicate that these sites were re-inhabited multiple times across millennia. An exception is Årvika (site 2 in the Markeila sub-area) located in a deep cove with a restricted outlook. After an initial intensive use-phase, the land uplift caused the withdrawal of the shoreline, eliminating the good landing conditions. Lacking this prerequisite, the site was abandoned.

Our reconstruction of local resource availabilities indicates that the coast around Sørøya was characterized by very high marine productivity throughout the year. It is noteworthy that peaks in species availability did not conflict with each other, but rather followed each other in neat successions: the winter fishing for migratory cod was followed by the haddock spawning, followed by the arrival of Harbour seal pups, nesting birds, salmon and pollock. The best period for reindeer hunting is the late summer and early autumn, when the hides are at their best quality. The following months of November and December were the leanest in terms of resource harvesting. However, stocks of dried meat, small-scale fishing of the near shore coastal cod and stationary seals could have provided valuable time for raw material preparation and equipment manufacture and mending, including skins for clothes and boats, during this period (Skandfer forthcoming).

While the resources would have allowed extended periods of habitation, possibly round the year, in each sub-area, some variation may be noted. The quantities of migrating cod are particularly prominent in Markeila and Breivikfjord. Since this winter fishing is also a 
season of storms, residing and fishing inside the two bays, avoiding open water, would have been optimal. Galtenfjord provided best access to the spawning haddock on the outer coast in the spring and for hunting of the large Grey seal. Although the settlements in the three southern sub-areas were located in sheltered positions, the best fishing grounds required journeys onto the open sea, and hence required favourable weather. They had more limited direct access to inland and outer coast resources but were on the other hand better placed to monitor both resources and human movement in the large sound. Hence, these areas may have been favoured during the light spring and summer periods.

The question of regional and supra-regional mobility patterns must be evaluated on a larger spatial scale and will not be addressed here. Our data suggest that round the year habitation within the study region was fully possible, but that relocation of residential groups or task groups between sub-areas could have optimized the exploitation of a diversity of resources.

While each sub-area is located in the vicinity of a number of resources, these are typically not found directly at the settlement, but require transportation over some distance. Boats allow people to travel over longer distances in a day than terrestrial foragers on foot, and to carry heavier and larger bulks (Bjerck 2017). However, there is much to suggest that coastal foragers generally did not journey far for daily resources. Ames (2002:36) indicate a foraging radius for marine foragers below $10 \mathrm{~km}$, and typically only 3.5 to $8 \mathrm{~km}$. A study of the faunal remains in eastern Finnmark emphasize that most of the catch was from the immediate vicinity of the sites (Hodgetts 2010). Our analysis from Sørøya demonstrates the same: the strategy was to locate sites relatively near resource hot spots rather than to exploit these from a few selected habitation areas further away. However, rather than map directly onto the local resources with the shortest possible distance, sites with good landing, outlook and shelter were preferred, and some journey distance to resources acceptable.

Furthermore, a spatial and temporal gradient of the relation between settlements and resources is observed: Fish, the staple and predictable resource, are found closest to the sites. Even today most small habitations know of a near-shore spot where a catch is practically guaranteed, if the weather is foul and stocks empty. Seal and bird cliffs were found some distance from the sites. While seals must have been an important resource, we know from other circumpolar areas that settlements were often located some distance from seal rookeries, to avoid disturbing the colonies (see also Bjerck 2009). Terrestrial species were typically best obtained from even further away and could require longer journeys by foot and/or by boat. This three-tiered spatial resource distribution appear to be found also in Newfoundland and to a certain extent in the Aleutians. This has been under-communicated as a strategic factor in spatial distribution of settlements in coastal areas.

Interestingly, the settlement patterns identified for early Holocene pioneer groups in Northern Norway differ markedly from the patterns now documented for mid-Holocene patterns in northernmost Norway, Newfoundland and the Aleutians. This could be a result of a combination of limited availability of protected sites in the early Holocene and the later transgression of such. It is, however, likely that also differences in species diversity and stability between the cold early Holocene Northern Norway and the warmer and more stable mid-Holocene with a possibly early emphasis on sealing and a later on fishing are part of the explanation (Bjerck 2017; Jørgensen 2020b). The early Holocene cold climate resources presumably had a higher degree of seasonality and fluctuation in quantity and location, resulting in an even greater need for monitoring the surroundings. The location of exposed sites is reminiscent of the exposed sites in Late Martitime Archaic on Newfoundland, associated with outlook for seal migrations. 
Population size is likely to have been another significant factor. In sparsely populated areas, social networks are fragile and need to be actively maintained to avoid isolation. In the early Holocene, the overall population density in Northern Norway appears to have been low and hence required more extensive mobility in order to sustain social and economic networks. The small sites, the limited number of dwelling remains and the ephemeral quality of these have been used in arguments for an extensive mobility. A Summed Probability Distribution model based on radiocarbon dates from northernmost Norway suggests population growth from c. 6000 BC with a peak around 4000 BC (Jørgensen 2020a). As climate and environment stabilized and resources became more predictable, not least due to an increasing emphasis on fish rather than seals, the population density increased and there was a noticeable packing in the coastal landscape. This resulted in decreased mobility as indicated by regionalization in raw material exploitation, learning networks and rock art styles (e.g. Bergsvik 2006; Skandfer 2009; Fuglestvedt 2018; Gjerde 2018). The new pattern was characterized by longer residential occupation at many sites, indicated by the increasing number of more substantial dwellings. The same semi-sedentary pattern with prolonged seasonal occupation of sites is found in the Aleutians. Longer residential stays let the inhabitants weigh the advantages of exposed locations directly at resources with better shelter but longer extraction time. The data from Sørøya point towards the operation of the latter solution. Interestingly, despite an assumption of greater mobility, only a smaller percentage of the sites from the Late Maritime Archaic on Newfoundland are located on more exposed locations. This may represent an intermediate position, and with exposed sites probably associated with harp seal migrations, but a majority of sites in coves from where to exploit a range of resources.

\section{Conclusions}

The present study demonstrates that high-resolution surveys offer the only way to generate the qualitative and contextual data needed to better understand some of the humanscale choices and strategies that lay behind coastal settlement patterns. Without the extensive surveys with systematic in-field and on-site documentation and discussions of landscape and resources neither the empirical results, nor the associated reconstruction of settlement choices and strategies could have been achieved. While for example deskbased GIS studies can pull out broad spatial patterns, a more qualitative field-based approach is required to understand the particular interplay between fine-grained local topography and the role of human choice in resolving tensions between local opportunities and constraints.

Northern mid-Holocene foragers were making decisions and trade-offs between where living was topographically possible, and the distance and access to resources. Their considerations included evaluation of the hazards of the harsh maritime environment, as well as a range of other factors including landing, monitoring points, shelter and access to alternative resources, but only secondarily fresh water.

On southwestern Sørøya year-round settlement was possible as far as subsistence resources were concerned. From the onset of a stable climate from the mid-Holocene, resources were stable and predictable. A few commodities such as larger quantities of reindeer or elk hides, terrestrial mammal bones and larger lithic nodules may have had to 
be retrieved from elsewhere but could in principle have been handled by task groups or through exchange.

Continuous habitation would have been possible for local populations within the study region, even for several years. In turn, this indicates that journeys to more distant locations was likely encouraged by other factors than seasonal resource sparsity. Motivations for residential relocation away from the study region and other long-distance mobility were more likely driven by social, political, ritual and non-subsistence economical purposes. Greater population density, more stable and predictable resources and semi-sedentary mobility patterns in the mid-Holocene appear to have led to greater emphasis on site location factors such as shelter and local resource diversity. Similar considerations and preferences appear to emerge also within analogous circumpolar settings such as Newfoundland and the Aleutians.

Supplementary Information The online version contains supplementary material available at https:/doi. org/10.1007/s11457-021-09316-x.

Funding The research was funded by the Norwegian Research Council under grant no 261760. Open Access funding provided by UiT The Arctic University of Norway.

\section{Declarations}

Conflict of interest The authors declared that there is no conflict of interest.

Open Access This article is licensed under a Creative Commons Attribution 4.0 International License, which permits use, sharing, adaptation, distribution and reproduction in any medium or format, as long as you give appropriate credit to the original author(s) and the source, provide a link to the Creative Commons licence, and indicate if changes were made. The images or other third party material in this article are included in the article's Creative Commons licence, unless indicated otherwise in a credit line to the material. If material is not included in the article's Creative Commons licence and your intended use is not permitted by statutory regulation or exceeds the permitted use, you will need to obtain permission directly from the copyright holder. To view a copy of this licence, visit http://creativecommons.org/licenses/by/4.0/.

\section{References}

Ames KM (2002) Going by boat. The Forager-Collector Continuum at Sea. In Fitzhugh, B. and Habu, J. (eds) Beyond Foraging and Collecting. Evolutionary Change in Hunter-Gatherer Settlement Systems. New York: Kluwer Academic/Plenum Publishes, 19-52

Andreassen RL (1984) Yngre steinalder på Sørøy. Bosetning og samfunn 4000-1000 f.Kr. Thesis, Tromsø: University of Troms $\emptyset$. https://www.nb.no/nbsok/nb/dc4a066bd7a8555d853a6701aefb9945?lang=no\#0

Andreassen RL, Bratrein HD (2011) Finnmark, Bjarkøy and the Norwegian kingdom. In: Olsen B, Urbańczyk P, Amundsen C (eds) Hybrid spaces. Novus, Oslo, pp 315-327

Barlindhaug S (1996) Hvor skal vi bygge og hvor skal vi bo? En analyse av lokaliseringsfaktorer $i$ tidlig elder steinalder $i$ Troms. Dissertation, Troms $\varnothing$ : University of Troms $\emptyset$

Bell T, Renouf P (2004) Prehistoric cultures, reconstructed coasts: maritime Archaic Indian site distribution in Newfoundland. World Archaeol 35(3):350-370. https://doi.org/10.1080/0043824042000185766

Bergsvik KA (2006) Ethnic boundaries in Neolithic Norway. BAR International Series 1554. Oxford: Archaeopress

Bjerck HB (1989) Forskningsstyrt kulturminneforvaltning på Vega, Nordland. En studie av stgeinaldermenneskenes boplassmønstre og arkeologiske letemetoder. Gunneria 61. Trondheim

Bjerck HB (1990) Mesolithic site types and settlement patterns at vega Northern Norway. Acta Archaeologica 60(1989):1-32

Bjerck HB (2009) Colonizing Seascapes: comparative perspectives on the development of maritime relations in scandinavia and patagonia. Arctic Anthropology. https://doi.org/10.1353/arc.0.0019 
Bjerck HB (2017) Settlements and seafaring: reflections on the integration of boats and settlements among marine foragers in early mesolithic Norway and the Yámana of Tierra del Fuego. J Island Coastal Archaeol 12(2):276-299. https://doi.org/10.1080/15564894.2016.1190425

Bjerck HB, Breivik HM, Piana EL, Zangrando AF (2016) Exploring the role of pinnipeds in the human colonization of the seascapes of Patagonia and Scandinavia. In: Bjerck HB, Breivik HM, Fretheim SE, Piana EL, Skar B, Tivoli AM, Zangrando AF (eds) Marine ventures: Archaeological Perspectives on Human-Sea Relations. Proceedings from the Marine Ventures Int. Symposium in Trondheim 2013. Sheffield, Equinox, 51-71

Damm CB (2021) Mesolithic pyro-technology: practices and perceptions in early holocene coastal Norway. Eur J Archaeol. https://doi.org/10.1017/eaa.2021.31

Damm C, Skandfer M (2020) Dokumentasjon av kulturminneområdet på ID 27272 Taborshamn, Hasvik kommune, Finnmark i 2018 under forskningsprosjektet «Stone Age Demographics». Septentrio Reports. https://doi.org/10.7557/7.5714

Damm CB, Skandfer M, Jørgensen EK, Sjøgren P, Vollan KWB, Jordan P (2020) Investigating long-term human ecodynamics in the european arctic: towards an integrated multi-scalar analysis of early and mid holocene cultural, environmental and palaeodemographic sequences in Finnmark County, Northern Norway. Quarternary International 549:52-64. https://doi.org/10.1016/j.quaint.2019.02.032

Engelstad E (1984) Diversity in arctic maritime adaptation. an example from the late Stone age of arctic Norway. Acta Borealia 2:3-24. https://doi.org/10.1080/08003838408580310

Fitzhugh B (2016) The origins and development of arctic maritime adaptations in the subarctic and arctic pacific. In: Friesen TM, Mason OK (eds) The Oxford Handbook of the Prehistoric Arctic. Oxford University Press, Oxford, pp 253-278

Fitzhugh W (1978) Maritime archaic cultures of the central and northern labrador coast. Arct Anthropol 15(2):61-95

Fuglestvedt I (2018) Rock art and the wild mind. visual imagery in mesolithic Northern Europe. Routledge, London

Frohlich B (2002) Aleutian Settlement distribution on Adak, Kagalaska, Buldier and Attu Islands. Aleutian Islands, Alaska. In: Frohlich B, Harper AB, Gilberg R (eds) The Aleutians and Beyond. The Anthropology of William S. Laughlin. Publications of The National Museum Ethnographical Series, vol. 20. Copenhagen: The National Museum of Denmark. 63-88

Gjerde JM (2010) Rock art and landscapes. studies of stone age rock art from Northern Fennoscandia. PhD-thesis. Tromsø: University of Troms $\emptyset$. https://hdl.handle.net/10037/2741

Gjerde JM (2018) An overview of Stone Age rock art in northernmost Europe-what, where and when? In: Rock Art of the White Sea. South-Korea: Ulsan Petroglyph Museum, 204-225

Günther T, Malmström H, Svensson EM, Omrak A, Sánchez-Quinto F, Kılınç GM et al (2018) Population genomics of Mesolithic Scandinavia: Investigating early postglacial migration routes and highlatitude adaptation. PLoSBiol 16(1):e2003703. https://doi.org/10.1371/journal.pbio.2003703

Grydeland SE (2000) Nye perspektiver på eldre steinalder i Finnmark. En studie fra indre Varanger. Viking LXII, 10-50

Grydeland SE (2005) The pioneers of Finnmark-from the earliest coastal settlements to the encounter with the inland people of Northern Finland. In: H. Knutsson, ed. Pioneer settlements and colonization process in the Barents region. Vuollerim. Vuollerim Papers on Hunter-Gatherer Archaeology $1,43-78$

Helskog E (1983) The Iversfjord locality. a study of behavioural patterning during the late stone age of Finnmark, North Norway. Troms $\emptyset$ Museums Skrifter XIX, Troms $\emptyset$.

Helskog K (1984) The younger stone age settlements in varanger, north Norway. Acta Borealia 1:39-69. https://doi.org/10.1080/08003838408580305

Helskog K (2014) Communicating with the world of beings. The World Heritage Rock Art Sites in Alta, Arctic Norway. Oxford: Oxbow books

Henriksen JE (2021) Rapport om tidlig marin ressursutnyttelse i Altafjord-området basert på tidlige historiske kilder. Septentrio Reports 3: «Stone Age Demographics» https://doi.org/10.7557/7.5758

Henriksen S, Valen CR (2013) Skjarvika og Fjellvika, Hammerfest kommune. Rapport fra de arkeologiske undersøkelsene 2009 og 2010. Tromura Kulturvitenskap 43. Troms $\varnothing$. Troms $\varnothing$ Museums Rapportserie

Hesjedal A, Damm C, Olsen B, Storli I (1996) Arkeologi på Slettnes. Dokumentasjon av 11.000 års bosetning. Troms $\emptyset$, Troms $\emptyset$ Museums Skrifter XXVI

Hesjedal A, Ramstad M, Niemi AR (2009) Undersøkelsene på Melkøya. Melkфya-prosjektet-kulturhistoriske registreringer og utgravninger 2001 og 2002. Tromura Kulturvitenskap 36. Troms $\emptyset$. Troms $\emptyset$ Museums Rapportserie 
Hodgetts L (2010) Subsistence diversity in the younger stone age landscape of varangerfjord Northern Norway. Antiquity 84(323):41-54. https://doi.org/10.1017/S0003598X00099750

Hughes ALC, Gyllencreutz R, Lohne ØS, Mangerud J, Svendsen JI (2016) The last Eurasian ice sheets-a chronological database and time-slice reconstruction, DATED-1. Boreas 45:1-45. https:// doi.org/10.1111/bor.12142

Johnson LL (1992) Prehistoric settlement patterns and population in the Shumagin Islands. Anthropol Pap Univ Alaska 24(1-2):73-88

Jørgensen EK (2020a) The palaeodemographic and environmental dynamics of prehistoric Arctic Norway: an overview of human-climate covariation. Quarternary International 549:36-51. https://doi. org/10.1016/j.quaint.2018.05.014

Jørgensen EK (2020b) Scalar effects in ground slate technology and the adaptive consequences for circumpolar maritime hunter-gatherers. J Archaeol Method Theory. https://doi.org/10.1007/ s10816-020-09458-7

Jørgensen EK, Jordan PJ, Vollan KWB (2019) Archaeological field survey of the Dønnesfjord Basin Outer Sørøya. Septentrio Reports. https://doi.org/10.7557/sr.2019.7

Martinson CR (1973) Aleut Settlements of the Makushin Bay Area, Alaska. PhD-thesis. Ann Arbor, Michigan: Department of Geography, University of Oregon, Xerox University Microfilms

Maschner HDG, Reedy-Maschner KL (1998) Raid, retreat, defend (Repeat): the archaeology and ethnohistory of warfare on the North Pacific Rim. J Anthropol Archaeol 17(1):19-51. https://doi.org/10. 1006/jaar.1997.0315

McCartney AP (1977) Prehistoric human occupation of the rat islands. In: Merritt, M. L. and Fuller, R. G. (eds) The Environment of Amchitka Island, Alaska, TID-26712. Prepared for division of military appreciation, Energy research and development administration. Prepared by technical information center, energy research and development administration, Washington, D.C. 59-113

Myrvoll M, Eythórsson E, Thuestad A, Bjetrkli B, Dalsbø ET, Eira RBM, Evjen B, Ravna Ø (2011) Felt 3. Sállan/Sфrфya. Sakkyndig utredning for Finnmarkskommisjonen. NIKU Oppdragsrapport 241. https://www.domstol.no/finnmarkskommisjonen/dokumenter/sakkyndige-utredninger/Feltvisesakkyndige-utredninger/

Møller JJ (1987) Shoreline relation and prehistoric settlement in northern Norway. Nor Geogr Tidsskr 41:45-60

Ólafsdóttir GÁ, Pétursdóttir G, Bárðarson H, Edvardsson R (2017) A millennium of north-east Atlantic cod juvenile growth trajectories inferred from archaeological otoliths. PLoS ONE 12(10):e0187134. https://doi.org/10.1371/journal.pone.0187134

Olsen B (1994) Bosetning og samfunn i Finnmarks forhistorie. Universitetsforlaget, Oslo

Renouf MAP (1989) Prehistoric Hunter-Fishers of Varangerfjord, Northeastern Norway, BAR International Series 487, Oxford

Romundset A, Bondevik S, Bennike O (2011) Postglacial uplift and relative sea level changes in Finnmark, northern Norway. Quarternary Sci Rev 30:2398-2421. https://doi.org/10.1016/j.quascirev.2011.06.007

Rowley-Conwy P (1999) Introduction: human occupation of the Arctic. World Archaeol 30(3):349-353. https://doi.org/10.1080/00438243.1999.9980416

Schanche K (1994) Gressbakkentuftene $i$ Varanger: boliger og sosial struktur rundt $2000 f$.Kr. Doctoral thesis. Tromsø: University of Tromsø. https://munin.uit.no/handle/10037/3317

Simonsen P (1979) Veidemenn på nordkalotten. Hefte 3: Yngre steinalder og overgang til metall tid. Stensilserie B 17. Troms $\varnothing$ : Institutt for samfunnsvitenskap, Universitetet i Troms $\varnothing$

Skandfer M (2009) "All change"? exploring the role of technological choice in the early northern comb ware of Finnmark, Arctic Norway. In: Zvelebil M (ed) Jordan, P. Left Coast Press, Ceramics before farming. The dispersal of pottery among prehistoric Eurasian hunter-gatherers. Walnut Creek, pp 347-374

Skandfer M forthcoming. Hunting for Hide. Investigating an Other-than-Food Relationship Between Stone Age Hunters and Wild Animals in Prehistoric Northern Europe. Submitted to Open Archaeology

Skandfer M, Damm C (2019) Dokumentasjon av tuftefelt i Hasvik kommune, Sørøya 2016 under forskningsprosjektet «Stone Age Demographics». Septentrio Reports. https://doi.org/10.7557/7.4857

Skandfer M, Vollan KWB, Damm C (2020) Dokumentasjon av tuftefelt i Hasvik kommune, Sørøya 2017, under forskningsprosjektet «Stone Age Demographics». Septentrio Reports. https://doi.org/10.7557/7. 5641

Sjøgren PJ, Damm C (2019) Holocene vegetation change in northernmost Fennoscandia and the impact on prehistoric foragers 12000-2000 cal. A BP-A review. Boreas, vol 48 (1), 20-35. https://doi.org/10. 1111/bor. 12344

Sørensen P (1956) Hasvik, Hasvik s., Loppa, pgd., Finnmark. Beretning om undersøgelser sommeren 1956 for Troms $\emptyset$ Museum. Unpublished report. Topografisk arkiv, Norges arktiske universitetsmuseum, UiT-Norges arktiske universitet 
Tuck JA, Pastore RT (1985) A Nice Place to Visit, but.... Prehistoric Human Extinctions on the Island of Newfoundland. Canadian Journal of Archaeology 9 (1), 69-80

Turner CG (1970) Archaeological reconnaissance of amchitka Island Alaska. Arct Anthropol 7(2):118-128

Vollan KWB in press. Adding people to the past: Discovering reuse of coastal Stone Age housepits in Arctic Norway by means of Bayesian modelling of radiocarbon dates. In: Færø, D. E. Olsen \& Jensen, T. (eds) The Stone Age Conference 2017. Proceedings from the third Stone Age Conference, Bergen 2017. Bergen: UBAS - University of Bergen Archaeological Series

Vollan KWB forthcoming. "Archaeological inferences under uncertainty: prehistoric dwellings, radiocarbon dates and the non-contemporaneity problem". Work in progress

\section{Online sources}

Askeladden Official database of protected heritage sites and cultural environments managed by the Directorate for Cultural Heritage in Norway. https://askeladden.ra.no/Askeladden/Pages/LoginPage.aspx? ReturnUrl=\%2faskeladden $\% 2 \mathrm{f}$

Den norske los (2018) https://www.kartverket.no/til-sjos/nautiske-publikasjoner/den-norske-los

Institute of Marine Research, Species: https://www.hi.no/en/hi/temasider/species

MUSIT The Norwegian Museum Database Initiative. https://wiki.uio.no/usit/musit/index.php/Brukerveil edning

Norwegian Biodiversity Centre (2020) Species observations https://www.artsdatabanken.no ; Accessed November 2020.

Norwegian Polar Institute, Wildlife in Polar Regions: https://www.npolar.no/en/species. Cod—northeast Arctic: https://www.hi.no/en/hi/temasider/species/cod--northeast-arctic

Coastal cod: https://www.hi.no/en/hi/temasider/species/costal-cod--north-of-the-62-latitude. Halibut: https://www.hi.no/en/hi/temasider/species/halibut. Pollock: https://www.hi.no/en/hi/temasider/species/ northeast-arctic-saithe

Publisher's Note Springer Nature remains neutral with regard to jurisdictional claims in published maps and institutional affiliations. 